\title{
Recent developments in the chemotherapy of HIV infections
}

\author{
Erik De Clercq \\ Rega Institute for Medical Research, Katholieke Universiteit Leuven, Minderbroedersstraat 10, B-3000 \\ Leuven, Belgium
}

\begin{abstract}
The HIV replicative cycle reveals several virus-specific events that could function as targets for chemotherapeutic intervention. The compounds that are presently available as anti-HIV drugs are targeted at either the substrate binding site of the reverse transcriptase (zidovudine, didanosine, zalcitabine, stavudine, lamivudine) or a non-substrate binding site of the reverse transcriptase (nevirapine, delavirdine), or the viral protease (saquinavir, ritonavir, indinavir, nelfinavir). Various other compounds targeted at either the reverse transcriptase or viral protease are still under clinical development, and so are a number of compounds that interact with other targets of the HIV replicative cycle. Remarkable clinical efficacy has been observed with combinations of different reverse transcriptase inhibitors and protease inhibitors. It may be anticipated that with the advent of newer and more efficient compounds the effectiveness of HIV inhibition could still be improved upon and the prospects for a definitive cure of the disease may be accomplished.
\end{abstract}

\section{INTRODUCTION}

The replicative cycle of human immunodeficiency virus (HIV) can be divided in ten steps: (i) virus adsorption to the cells; (ii) virus-cell fusion; (iii) virus uncoating; $(\underline{i v})$ reverse transcription; ( $\underline{v})$ proviral DNA integration; ( $\underline{\nu}$ ) proviral DNA replication; ( $\underline{v i i}$ ) proviral DNA transcription to viral messenger RNA; ( $\underline{v i i}$ ) viral messenger RNA translation to viral precursor proteins; $(\underline{i x})$ viral maturation (proteolysis, myristoylation, glycosylation); $(\underline{x})$ budding (release). All these steps could be considered as targets for chemotherapeutic intervention. Among these targets, particularly the reverse transcription and viral maturation (proteolysis) step have been most intensively pursued in the chemotherapy of HIV infections, but, in addition to the reverse transcriptase and viral protease inhibitors, various other compounds (Table 1), interacting with targets other than the reverse transcriptase and protease, also offer great potential for the chemotherapy of HIV infections [1-6].

\section{VIRUS ADSORPTION INHIBITORS}

Virus adsorption depends on the interaction of the viral envelope glycoprotein gp 120 with the CD4 receptor at the cell surface. This process can be blocked by various polyanionic substances such as polysulfates, polysulfonates, polycarboxylates, polyphosphates and polyoxometalates. Typical examples of this class of polyanionic substances are dextran sulfate, dextrin sulfate, polyvinylalcohol sulfate (PVAS), polyvinyl sulfonate (PVS), suramin, and naphthalene sulfonate polymers (i.e. PRO 2000).

In fact, suramin was the very first compound that was identified as an anti-HIV agent [7]. It was later shown to exert its anti-HIV activity through an interaction with the virus-cell binding process [8]. Suramin can be considered as an hexasulfonate and thus its, interaction with the virus adsorption process can be attributed to the polyanionic character of the compound. Suramin was also the first anti-HIV agent to be used in the clinic for the treatment of HIV infection [9].

Suramin was administered once a week at a dose of $1 \mathrm{~g}$ by the intravenous route [9]. As plasma drug levels of suramin built up after each weekly injection, the virus disappeared from the plasma. However, when therapy was stopped, the virus reappeared, suggesting that during suramin therapy the replication of HIV was suppressed but the virus was not eradicated from the organism. More recent studies with newer compounds have essentially revealed the same effect, that is suppression but not eradication of the virus during the treatment period. In this aspect the original results obtained with suramin (which was later discontinued for the treatment of HIV infections because of toxicity) heralded the results that would be achieved with the more modern and more potent anti-HIV drugs. 
TABLE 1. Anti-HIV agents, steps in the replicative cycle of HIV inhibited by the anti-HIV agents and molecular targets for their interaction

\begin{tabular}{|c|c|c|}
\hline Virus replicative step & Compounds* & Molecular targets \\
\hline Virus adsorption & $\begin{array}{l}\text { Polyanions: } \\
\text { - polysulfates (dextran sulfate) } \\
\text { - polysulfonates (suramin, PRO 2000, } \\
\text { NSC-651016) } \\
\text { - polycarboxylates (ATA) } \\
\text { - polyoxometalates (POMs) } \\
\text { - polyphosphates [zintevir (AR177)] }\end{array}$ & $\begin{array}{l}\text { Envelope glycoprotein gp120 } \\
\text { (V3 loop) }\end{array}$ \\
\hline Virus-cell fusion & $\begin{array}{l}\text { Negatively charged albumins (Suc-HSA, } \\
\text { Aco-HSA) } \\
\text { Oligopeptides (pentafuside T20) } \\
\text { Betulinic acid derivatives (RPR 103611) } \\
\text { Bicyclam derivatives (AMD 3100) }\end{array}$ & $\begin{array}{l}\text { Envelope glycoprotein gp } 120 \\
\text { Envelope glycoprotein gp41 } \\
\text { CXCR4 (fusin) coreceptor }\end{array}$ \\
\hline $\begin{array}{l}\text { Virus uncoating } \\
\text { (disassembly) and virus } \\
\text { assembly }\end{array}$ & $\begin{array}{l}\text { Dithiobisbenzamides (DIBAs, SRR-SB3) } \\
\text { ADA (1,1'-azobisformamide) } \\
\text { Cyclosporin A analogue }\end{array}$ & $\begin{array}{l}\text { Nucleocapsid protein } \mathrm{p} 7 \\
\text { (zinc fingers) } \\
\text { Cyclophilin A }\end{array}$ \\
\hline Reverse transcription & $\begin{array}{l}\text { Nucleoside reverse transcriptase inhibitors } \\
\text { (NRTIs: AZT, DDI, DDC, D4T, 3TC, 1592U89) } \\
\text { Nucleotide reverse transcriptase inhibitors } \\
\text { (NRTIs) or acyclic nucleoside phosphonates } \\
\text { (ANPs): PMEA, PMPA } \\
\text { Nonnucleoside reverse transcriptase inhibitors } \\
\text { (NNRTIs: nevirapine, delayirdine, loviride, } \\
\text { tivirapine, MKC-442, DMP-266, quinoxaline } \\
\text { HBY 097, thiocarboxanilide UC-781) }\end{array}$ & $\begin{array}{l}\text { Reverse transcriptase } \\
\text { nonsubstrate-binding site }\end{array}$ \\
\hline Proviral DNA integration & $\begin{array}{l}\text { Dicaffeoylquinic acids, AR177 (zintevir), } \\
\text { oligopeptides, depsides, depsidones and } \\
\text { hydrazide-based compounds }\end{array}$ & $\begin{array}{l}\text { Integrase ( } 3 \text { '-processing, strand } \\
\text { transfer, disintegration, ligation) }\end{array}$ \\
\hline $\begin{array}{l}\text { Proviral DNA transcription } \\
\text { to mRNA }\end{array}$ & $\begin{array}{l}\text { Benzodiazepin (Ro 5-3335) and non- } \\
\text { benzodiazepin derivatives (GCPK) } \\
\text { Oligopeptides } \\
\text { Peptoids (CGP 64222) } \\
\text { Adenosine analogues (neplanocin A) }\end{array}$ & $\begin{array}{l}\text { Tat transactivation process } \\
\text { Tat core domain } \\
\text { Tat/TAR interaction } \\
\text { S-adenosylhomocysteine } \\
\text { hydrolase }\end{array}$ \\
\hline Viral mRNA translation & Ribozymes, antisense oligonucleotides & Viral mRNA \\
\hline Viral protein maturation & $\begin{array}{l}\text { Proteolysis inhibitors (saquinavir, ritonavir, } \\
\text { indinavir, nelfinavir, VX-478, DMP-323, KNI- } \\
\text { 272, CGP61755, RPI 312, PNU-140690) } \\
\text { Myristoylation inhibitors } \\
\text { Glycosylation inhibitors (N-butyldeoxynojiri- } \\
\text { mycin) }\end{array}$ & $\begin{array}{l}\text { Viral protease (responsible for } \\
\text { proteolytic cleavage of viral } \\
\text { precursor proteins) } \\
\text { Myristoylation of Gag precursor } \\
\text { protein } \\
\alpha \text {-Glucosidase involved in } \\
\text { glycosylation of viral envelope } \\
\text { glycoproteins }\end{array}$ \\
\hline
\end{tabular}

*Compounds that have been formally approved for the treatment of HIV infections are underlined. 
In addition to suramin, numerous other polyanionic compounds [1,2] have been shown to block HIV infection through interference with the virus adsorption process. Among the polysulfonates, PRO 2000 [10] and NSC-651016 [11] offer particular promise for the systemic treatment of HIV infections. Other polyanionic substances [1,2] that have been found to interfere with the HIV adsorption process are the polycarboxylates such as the aurintricarboxylate acid (ATA) polymer, polyoxymetalates (POMs) of either the Keggin or Dawson type, and inorganic polyphosphates [12].

Yet another example of a polyanionic substance is the polynucleotide zintevir (AR177), a 17-mer oligodeoxynucleotide that solely consists of thymine and guanine as the heterocyclic moieties and which forms two stacked G-quartets that can bind a potassium ion in the middle. Zintevir has been shown to interfere with the virus adsorption process, although additionally it can also interfere with the viral integrase [13]. Nevertheless, its mechanism of anti-HIV action in cell culture systems can be attributed to an interaction at the virus adsorption level [14].

Polyanionic substances may offer great potential in the prophylaxis of HIV infections when applied topically, for instance in gel or cream form to prevent HIV infection by sexual transmission $[15,16]$ Initial clinical studies indicate that such gels may be well tolerated intravaginally [17]. An additional bonus of the polyanionic compounds is that they are not only effective against HIV but also against some other enveloped viruses such as herpes simplex virus type 1 (HSV-1) and type 2 (HSV-2), human cytomegalovirus (HCMV), influenza A virus, respiratory syncytial virus and arena- and rhabdoviruses.

\section{VIRUS-CELL FUSION INHIBITORS}

Virus-cell fusion is initiated by the interaction of the viral envelope gp120 with the co-receptor CXCR4 (fusin) (lymphocytic-tropic viruses) or CCR5 (macrophage-tropic viruses), which, like the CD4 receptor, are also embedded in the outer cell membrane and which normally serve as chemokine receptors. When gp 120 is stripped from the viral envelope, the other envelope glycoprotein gp41 is uncovered so that it can anchor in the cell lipid membrane and ensure the fusion between the lipid bilayers of the virus envelope and the outer cell membrane. Chemokine receptor antagonists (i.e. AOP-RANTES) that achieve full receptor occupancy at nanomolar concentrations have been considered as strong candidates for the therapy of HIV infections [18].

The virus-cell fusion process can be inhibited by the negatively charged albumins (NCAs) such as Suc-HSA (succinylated human serum albumin) and Aco-HSA (aconitylated human serum albumin) [19-22]. Other examples of virus-cell fusion inhibitors are the betulinic acid derivatives (i.e. RPR 103611) [23], siamicin I (NP-06) [24,25] and pentafuside T20. The latter corresponds to a 36 amino acid region in the gp41 glycoprotein [26] and interferes with the fusogenic activity of gp41. Also, RPR 103611 would directly interfere with the glycoprotein gp41 [27].

Highly specific fusion inhibitors are the bicyclam derivatives (prototype AMD 3100 , previously referred to as JM 3100 ), which contain two cyclam moieties that are tethered through an aliphatic or aromatic bridge [28,29]. AMD 3100 inhibits HIV replication at nanomolar concentrations, while not being toxic to the host cells at a concentration of $500 \mu \mathrm{M}$. This results in a selectivity index of more than 100,000 . Hence, the bicyclam AMD 3100 can be considered as one of the most potent and selective anti-HIV agents that have been described so far.

AMD 3100 has been shown to cause a dose-dependent decrease in viremia in vivo, in SCID-hu Thy/Liv mice infected with HIV-1 [30]. It has taken more than 60 passages (300 days) in vitro, in MT-4 cells, for the virus to become only partially resistant to JM3100 [31]. Several mutations, most of them located in the V3 loop of the viral gp120 glycoprotein were detected, which together must have contributed to the resistant phenotype [32]. We have recently found that the bicyclam AMD3100 binds tightly and specifically with the CXCR4 (fusin) [33], and in doing so the bicyclams represent the first low molecular weight compounds shown to inhibit HIV infectivity and HIV cell fusion through binding to the HIV coreceptor CXCR4 (fusin) [34].

\section{VIRUS UNCOATING INHIBITORS}

Virus uncoating can be envisaged as the dissociation of the viral envelope glycoproteins and viral capsid proteins from the viral genome, which is required for the next step (reverse transcription) to take place. The last protein to be dissociated from the viral genome is the nucleocapsid (NC) protein $\mathrm{p} 7$, which contains two zinc fingers. This protein is believed to be the target of action for the 2,2'-dithiobisbenzamides (DIBAs) [35-40]. DIBAs are able to 
interfere with both early and late phases of HIV replication. Their effect at the late phase (assembly) results in an abnormal processing of the gag precursors (due to the formation of intermolecular cross-linkages among the zinc fingers of adjacent Gag molecules) and the release of noninfectious virus particles [39]. Their effect at the early phase (disassembly) may be ascribed to extensive cross-linkage among adjacent zinc fingers of adjacent NC p7 molecules. DIBAs are able to enter intact virions, and the cross-linkage of $\mathrm{NC} \mathrm{p} 7$ in virions correlates with loss of infectivity and decreased priviral DNA synthesis during acute infection [40].

We have recently described a macrocyclic 2,2 '-dithiobisbenzamide SRR-SB3 that may also achieve its anti-HIV activity through interaction with the NC protein p7 [41]. From time-of-addition experiments [41] whereby the compound was added at different times after HIV infection, we concluded that the SRR-SB3 may interact with a late stage of virus replication, which may correspond to the assembly of the virus particles. Thus, 2,2'dithiobisbenzamides may interact with both the uncoating (disassembly) and the maturation (assembly) processes (as the NC protein $\mathrm{p} 7$ is involved in both processes).

In addition to the DIBAs and SRR-SB3, the 1,1'-azobisformamide (ADA) may also owe its, albeit weak anti-HIV activity [42] to an interaction with the NC protein $\mathrm{p} 7$ zinc fingers [43].

The nonimmunosuppressive cyclosporin A analogue [Melle ${ }^{4}$ cyclosporin (SDZ NIM 811) represents another class of molecules that interfere at two stages of the HIV replicative cycle: (i) translocation of the preintegration complex from the cytoplasm to the nucleus and (ii) production of infectious virus particles [44]. The target for the anti-HIV action of $\left[\mathrm{MeIle}^{4}\right]$ cyclosporin is cyclophilin A which, through its peptidyl-prolyl cis-trans isomerase activity, assists in the folding of proteins [45]. Cyclophilin A interacts with the HIV-1 Gag polyprotein and is incorporated in the HIV-1 virions. [MeIle ${ }^{4}$ ]cyclosporin disrupts the Gag-cyclophilin A interaction [46] and inhibits cyclophilin A incorporation into virions [47]. Consequently, [Melle ${ }^{4}$ cyclosporin causes a dose-dependent inhibition of the formation of infectious virus particles [48,49], and this dose-dependent reduction in infectivity is directly correlated with a reduction in the amounts of virion-associated cyclophilin A [50].

\section{REVERSE TRANSCRIPTION INHIBITORS}

Reverse transcriptase catalyses the conversion of the single-stranded viral RNA genome to the double-stranded proviral DNA which will be subsequently integrated into the cellular DNA genome. Several domains have been characterized in the reverse transcriptase (RT) heterodimer (p66/p41), of which the palm domain is involved in the catalytic process. There are two targets in this palm domain: the substrate binding site and a non-substrate binding site, which correspond to the binding sites for the nucleoside/nucleotide RT inhibitors (NRTIs) and non-nucleoside RT inhibitors (NNRTIs), respectively [51].

Of the NRTIs, five compounds have been approved for the treatment of HIV infections: zidovudine (AZT), didanosine (DDI), zalcitabine (DDC), stavudine (D4T) and lamivudine (3TC). All these compounds act in a similar fashion: they need to be phosphorylated intracellularly in three steps to the 5'-triphosphate form, which then interacts at the level of the RT as a competitive inhibitor/alternate substrate. If the inhibitor is incorporated into the DNA chain, further elongation of the DNA chain will become impossible. In this respect, the ddNTPs or 5'triphosphates of AZT, DDI, DDC, D4T and 3TC behave as DNA chain terminators $[1,2]$.

Recently, a novel carbocyclic nucleoside analogue, 1592U89, or (-)-(1S,4R)-4-[2-amino-6-(cyclopropylamino)-9Hpurin-9-yl]-2-cyclopentene-1-methanol, has been described as a potent and selective inhibitor of HIV replication $[52,53]$. This compound can be considered as a prodrug of the monophate of carbovir to which it is converted intracellularly through the consecutive action of adenosine phosphotransferase (which converts $1592 \mathrm{U} 89$ to 1592 U89 monophosphate) and a novel cytosolic enzyme (which converts 1592 U89 monophosphate to carbovir monophosphate); the latter is then further phosphorylated to carbovir triphosphate by cellular kinases [54], and carbovir triphosphate, akin to the other ddNTPs, then acts as a chain terminator of the RT-driven DNA synthesis. 1592 U89 has excellent oral bioavailability and penetrates into the central nervous system; it has progressed to clinical evaluation in HIV-infected patients.

The crucial factor in the anti-HIV activity of the nucleoside analogues is the first phosphorylation step. This phosphorylation from the nucleoside to the nucleotide stage determines why some nucleoside analogues are active as anti-HIV agents whereas others are not and also why nucleoside analogues may be more effective in cells or tissues that have a higher phosphorylating capacity than other cells or tissues. To circumvent this phosphorylation problem we have conceived a class of compounds that are referred to as nucleotide analogues and which correspond 
to acyclic nucleoside phosphonates. The prototypes of this class of compounds are PMEA [9-(2phosphonylmethoxyethyl)adenine] and PMPA [(ㅁ)-9-(2-phosphonylmethoxypropyl)adenine]. These compounds need only two phosphorylations to be converted to the active (diphosphate) form, i.e. PMEApp and PMPApp, which then interact as chain terminators at the RT level.

The acyclic nucleoside phosphonates PMEA and PMPA have proved to be potent and selective inhibitors of retrovirus (i.e. HIV) replication, in cell culture, animal models and humans $[55,56]$. Since these compounds are not sufficiently bioavailable by the oral route, they have been formulated in an oral prodrug form, i.e. bis(POM)PMEA and bis(POC)PMPA. Bis(POM)PMEA is now in advanced clinical trials and bis(POC)PMPA has just entered clinical trials in HIV-infected individuals. Both compounds offer great promise for the treatment of HIV infections. They may be administered in a convenient way, that is one oral dose per day; they are not only active against HIV but also against hepatitis B virus (HBV). PMEA is also active against the replication of HCMV and may be expected to be effective in the prophylaxis of HCMV infections. PMPA, on the other hand, has proved to completely prevent simian immunodeficiency virus infection (SIV) in Rhesus macaques monkeys [57].

Of the NNRTIs, two compounds have presently been approved, namely nevirapine and delavirdine, and several others are in either clinical or preclinical development [3]: loviride, MKC-442, tivirapine (TIBO R86183), DMP266, HBY 097 and the thiocarboxanilides [58]. All these compounds, although belonging to different chemical classes, assume a butterfly-like conformation [3]. They dock into a pocket ("niche") located in the vicinity of the substrate binding site of HIV-1 RT. Consequently, the NNRTIs allosterically distort the polymerase active site.

Although all the NNRTIs occupy the same pocket within the HIV-1 RT, some differences have been noted in the binding modalities among the different NNRTIs, as demonstrated, for example, for delavirdine [59]. These differential binding modalities are also reflected in the resistance mutations profiles of the different NNRTIs which only partially overlap [5]. The NNRTIs are highly specific for HIV-1. They are of generally low toxicity, but their clinical use has been limited by the rapid selection for resistant virus mutants. Different mutation patterns in the HIV-1 RT may be selected depending on the drug doses used [60], but the emergence of these mutations may be prevented if the drugs are used in combination from the start at sufficiently high doses (see infra).

\section{PROVIRAL DNA INTEGRATION INHIBITORS}

Proviral DNA integration into the cell DNA genome encompasses several steps (i.e. 3 '-processing, strand transfer, disintegration, ligation) which makes it a priori a hard task to conceive specific inhibitors for any of these steps. There are a number of compounds that have been reported to interfere with the integration process: among them, zintevir, which is also known to block the virus adsorption process [13,14]. Zintevir would inhibit the HIV-1 integrase by preventing the formation of the initial stable complex between integrase and substrate DNA [61]. It is not obvious, however, that the integrase-inhibiting effect of zintevir would contribute to its anti-HIV activity in cell culture, as time-of-addition experiments [13] and resistance mutation studies [14] point to the viral envelope glycoprotein gp120, rather than the integrase, as the main target for the anti-HIV action of zintevir. Likewise, dextran sulfate has been found to inhibit HIV-1 integrase in a cell-free system [61], although there is ample evidence, based on virus-cell binding studies, time-of-addition experiments [28], as well as the analysis of resistance mutations [62], that dextran sulfate owes its anti-HIV activity to inhibition of the virus adsorption/fusion process.

There are a number of compounds, i.e. 3,5-dicaffeoylquinic acid, 1-methoxyoxalyl-3,5-dicaffeoylquinic acid and L-. chicoric acid that have been reported to inhibit both HIV-1 integrase (at concentrations ranging from 0.06-0.66 $\mu \mathrm{g} / \mathrm{ml}$ ) and HIV-1 replication in cell culture (at $1-4 \mu \mathrm{g} / \mathrm{ml}$ ) [63]. These compounds were found to inhibit the core catalytic domain of HIV-1 integrase and the calculated change in internal free energy of the ligand-integrase complex correlated with the ability of the compounds to inhibit HIV-1 integrase [64]. What remains to be shown, however, i.e. by time-of-addition experiments is whether the inhibitory effects of the dicaffeoylquinic acid derivatives on HIV-1 integrase could really account for their inhibitory effects on virus replication.

Depsides, depsidones [65] and hydrazide-bearing compounds [66] have been described as integrase inhibitors, and a synthetic peptide corresponding to the 147-175 amino acid region of the integrase was found to interfere with the integration activity of the enzyme due to its ability to bind to the integrase through a peptide-protein coiled-coil interaction [67]. 
Diarylsulfones represent yet another class of HIV-1 integrase inhibitors [68], although it is not clear to what, if any, extent, the inhibitory effects of the diarylsulfones on HIV-1 integrase contribute to their inhibitory effects on HIV replication. In fact, no correlation was found between the $50 \%$ inhibitory concentrations $\left(\mathrm{IC}_{50}\right)$ of these compounds for the viral integrase and their $\mathrm{IC}_{50}$ values for virus replication. Other compounds, i.e. NSC 158393 (which contains four 4-hydroxycoumarin residues), have been reported to inhibit both HIV-1 integrase and protease [69]. While such dually targeted action could, in principle, be considered as an interesting approach to achieve synergistic anti-HIV activity and reduce the risk of resistance development, it is not evident whether the antiviral activity of these compounds in cell culture is due to inhibition of either, both or neither of these two enzymes.

\section{PROVIRAL DNA REPLICATION INHIBITORS}

No inhibitors are known that specifically interfere with the replication of the proviral DNA.

\section{PROVIRAL DNA TRANSCRIPTION INHIBITORS}

The Tat (trans-acting transactivation) process that stimulates the DNA-dependent RNA transcription starting from the long terminal repeat (LTR) promotor has been envisaged as an appropriate target for chemotherapeutic intervention. Both benzodiazepin (i.e. Ro 5-3335) and non-benzodiazepin derivatives [i.e. 2-glycineamide-5chlorophenyl 2-pyrryl ketone (GCPK)] have been identified as Tat-dependent transcription inhibitors ("Tat antagonists") [70,71]. These compounds are effective against both acute and chronic HIV-1 infections and may be assumed to inhibit HIV-1 replication through their anti-Tat activity. The exact molecular target(s) of the Tat antagonists remain to be defined. This target may well be a cellular protein(s) involved in the Tat transactivation process, as the effectiveness of the Tat antagonists in blocking HIV-l replication strongly depends on the host cell type [72].

LTR transactivation can be blocked by peptide analogues of the Tat core domain (amino acids $36-50$ ), which, in turn, leads to downregulation of viral mRNA synthesis [73]. Similarly, peptoid/peptide oligomers of nine residues (CGP 64222) that block the interaction of the TAR RNA with Tat [74] have also been found to suppress HIV replication in cell culture.

Another class of compounds that interact with the Tat transactivation process are the carbocyclic adenosine analogues (i.e., neplanocin A, 3-deazaneplanocin A, 5'-noraristeromycin). These compounds have since long been known as broad-spectrum antiviral agents and inhibitors of the S-adenosylhomocysteine (SAH) hydrolase [75] and they lead to an accumulation of SAH which is a product/inhibitor of transmethylation reactions that depend on Sadenosylmethionine (SAM) as the methyl donor. These transmethylations reactions are assumed to play a role in the maturation of viral mRNAs and they may also be involved in the formation of mature HIV mRNA from the proviral DNA. This could then explain the inhibitory effect of the carbocyclic adenosine analogues on the HIV mRNA transcription process. We have recently demonstrated a close correlation between the inhibitory effects of the carbocyclic adenosine analogues on SAH hydrolase activity, HIV-1 Tat transactivation and HIV-1 replication $[76]$.

\section{VIRAL MESSENGER RNA TRANSLATION INHIBITORS}

The viral mRNA can serve as the target for oligonucleotides (i.e., ribozymes, antisense oligonucleotides) that specifically hybridize with well-defined nucleotide sequences in the viral $\mathrm{mRNA}$. Antisense oligonucleotides can be designed to target specific sequences of the HIV genome and may interfere with several steps in the HIV replicative cycle, i.e. reverse transcription, viral RNA transcription, viral RNA translation, and even virus adsorption (the latter through a non sequence-specific effect). For example, oligonucleotides targeted to the $U_{5}$ region (within the LTR promotor) or to a site adjacent to the primer binding site inhibit the reverse transcription reaction and thus proviral DNA synthesis [77]. However, most of the antisense oligonucleotides have been designed with the aim of inhibiting the translation of viral mRNAs to viral proteins [78].

A representative example is the 25-mer oligodeoxynucleotide phosphorothioate GEM 91 (GEM standing for "gene expression modulator") which is complementary to the AUG site of the gag region of the HIV-1 genome. GEM 91 hybridizes with this site, thereby blocking translation of the gag mRNA. It has been found to inhibit the replication of various strains of HIV-1 in different cell systems within the concentration range of $0.1-1 \mu \mathrm{M}$ [79]. GEM 91 
could be considered as the prototype of antisense oligonucleotides to be developed as a therapeutic agent for the treatment of HIV-1 infections [80]. Second generation antisense oligonucleotides with improved target affinity and anti-HIV activity have already been developed [81].

\section{VIRAL PROTEIN MATURATION INHIBITORS}

During the assembly process of the viral particles, the precursor viral proteins have to undergo a number of modifications (proteolytic cleavage, myristoylation and glycosylation), which could serve as targets for chemotherapeutic intervention. Glycosylation is required for the maturation of the viral envelope glycoproteins (i.e. gp120 and gp41), and glycosylation inhibitors such as $\mathrm{N}$-butyldeoxynojirimycin (which interacts with $\alpha$ glucosidase) have been shown to suppress virus infectivity by reducing the virion gp 120 content and causing a qualitative defect within the remaining gp120 [82].

During the viron maturation process the precursor proteins Pr 55 gag and Pr 160 gag-pol need to be cleaved by the HIV protease into the mature capsid proteins ( $17, \mathrm{p} 24, \mathrm{p} 9, \mathrm{p} 7$ ) and enzymes (protease, reverse transcriptase, integrase). HIV protease inhibitors have been tailored after the peptide linkage that is normally cleaved by the HIV protease. Thus, in the protease inhibitors the hydrolysable peptide linkage has been replaced by a non-hydrolysable hydroxyethylene bond, and this motif is present in the different protease inhibitors that have so far been approved (saquinavir, ritonavir, indinavir and nelfinavir) and others (i.e. VX-478, KNI-272, RPI 312) that are still under development for the treatment of HIV infections [5].

Numerous HIV-1 protease inhibitors have been designed. Most of these protease inhibitors, including those that have been formally approved, can be considered as peptidomimetic (substrate analogues). More recently, several nonpeptidic protease inhibitors, based on a 7-membered cyclic urea (i.e. DMP-323), sulfone or sulfamide [83-86] or dihydropyrone (i.e. PNU-140690) [87] have been developed that offer great potential for HIV chemotherapy. PNU140690 is highly active against HIV-1 variants resistant to peptidomimetic protease inhibitors, underscoring the structural distinctions between the nonpeptidic and substrate analogue protease inhibitors [87].

Protease inhibitors, such as indinavir, have been shown to cause a dramatic decrease in plasma HIV RNA load, paralleled by a concomitant increase in the $\mathrm{CD} 4^{+}$counts [88]. The stimulatory effect of indinavir on $\mathrm{CD}^{+}$counts and its inhibitory effect on viral load seem to be more pronounced than that of the nucleoside analogues AZT and 3TC combined [88]. The effectiveness of the protease inhibitors could be further enhanced when combined with reverse transcriptase inhibitors or when combined with one another [5]. In particular, ritonavir has been shown to favorably alter the pharmacokinetic profile of other protease inhibitors such as saquinavir [89].

\section{VIRUS BUDDING (RELEASE) INHIBITORS}

No inhibitors are known that specifically interfere with the virus budding (release) process.

\section{OUTLOOK FOR THE CHEMOTHERAPY OF HIV INFECTIONS}

All the HIV inhibitors may be expected to select for mutations that engender resistance to the compounds. This resistance development may obviously compromise the clinical usefulness of the different anti-HIV agents. Therefore, strategies should be envisaged to circumvent or prevent the development of HIV drug resistance [5]. One such strategy is based on the use of the compounds from the beginning at sufficiently high concentrations so as to completely suppress the virus so that it has no opportunity to develop resistance (Table 2).

We have found that NNRTIs such as nevirapine, delavirdine, loviride and tivirapine are able to completely prevent virus breakthrough when applied to the cells at a sufficiently high concentration (i.e. $2.5 \mu \mathrm{g} / \mathrm{ml}$ ), whereas at lower concentrations (i.e. 0.1 or $0.5 \mu \mathrm{g} / \mathrm{ml}$ ) they only temporarily prevent virus breakthrough [90]. The quinoxaline S2720 completely prevents virus breakthrough if used at a concentration as low as $0.1 \mu \mathrm{g} / \mathrm{ml}$ [91]. Furthermore, when the virus-infected cells that had been exposed to the quinoxaline $\mathrm{S} 2720$ at $0.1 \mu \mathrm{g} / \mathrm{ml}$ were analyzed by multiple cycles of PCR for the presence of proviral DNA, no such proviral DNA could be detected. This suggests that virusinfected cells that had been passaged in the presence of this anti-HIV agent had completely lost the proviral DNA, which in turn suggests that the cells had been cleared ("cured") from the virus. Further experiments [92] have indicated that the "newer" NNRTIs such as quinoxaline HBY 097 and thiocarboxanilide UC 781 are able to prevent 
virus breakthrough for a longer time and at a lower concentration than the "older" compounds such as nevirapine and BHAP U-88204.

When different compounds are combined, such as 3TC with MKC-442, or 3TC with delavirdine, or 3TC with thiocarboxanilide, virus breakthrough may be delayed for much longer time than when the compounds are used individually [93]. For example, 3TC at a concentration of $0.1 \mu \mathrm{g} / \mathrm{ml}$ delays virus breakthrough for about 10 days and so does MKC-442 at a concentration of $0.04 \mu \mathrm{g} / \mathrm{ml}$, but if both $3 \mathrm{TC}$ at $0.1 \mu \mathrm{g} / \mathrm{ml}$ and MKC -442 at $0.04 \mu \mathrm{g} / \mathrm{ml}$ are combined, they can delay virus breakthrough for more than 50 days.

What we have learned from these in vitro cell culture experiments is that anti-HIV drug regimens that are administered from the beginning at sufficiently high concentrations (which may be substantially lowered if different compounds are combined), may completely suppress virus replication and thus prevent resistance from emerging. The in vivo data obtained with the currently available anti-HIV drugs in patients tend to confirm these relatively simple principles [94]. Sequential drug monotherapy whereby one drug is substituted for another should be avoided [95]. The minimum goal of therapy should be to suppress HIV replication as much as possible for as long as possible. Allowing for residual HIV replication will invariably lead to outgrowth of drug-resistant virus and therapy failure [94].

TABLE 2. Recommendations for the clinical use of anti-HIV drugs

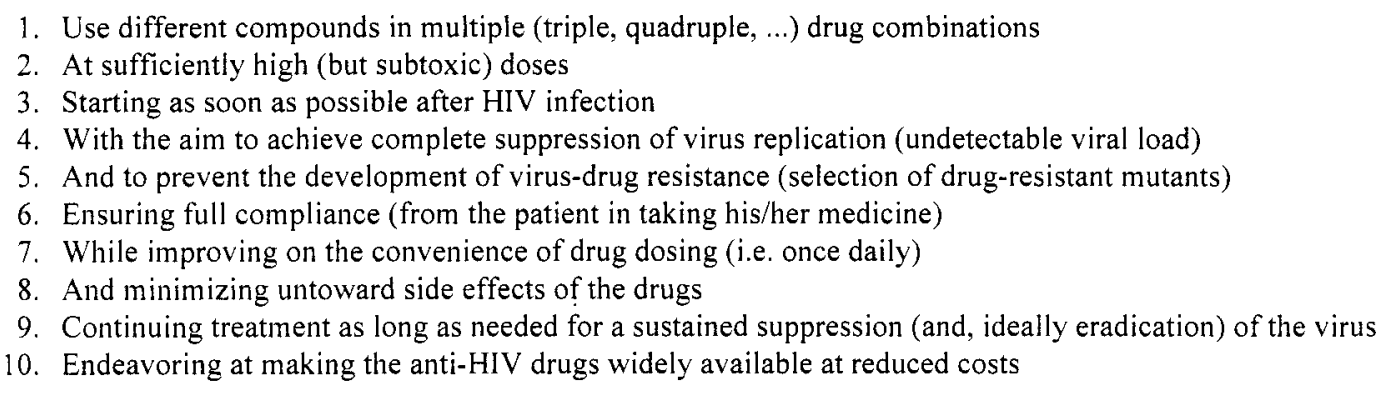

The general consensus now is that in adults as well as children [96] therapy with potent combinations of anti-HIV drugs should be started as early as possible after the infection has been acquired. There are, at present, eleven antiHIV drugs that have been approved, and another two dozens of compounds are in clinical or preclinical development. This means that numerous multiple (i.e. triple, quadruple, ...) drug combinations could be concocted. The search for the optimal drug combination will have to be guided by several criteria, such as availability from the supplier, convenience of administration, compliance by the patient, and drug-drug interactions in the organism.

The aim of the future anti-HIV therapy (Table 2) will be based on the installment of the multiple (i.e., triple, quadruple, ...) drug combinations as early as possible during the course of the HIV infection whenever there is evidence of ongoing HIV replication. The compounds should be used at sufficiently high doses so as to completely suppress virus replication. If different compounds are combined, the doses could be lowered so as to still generate a complete antiviral response in the absence of untoward side effects. Mellors et al. [97] have pointed out that the risk for the development of AIDS is directly proportional to the initial plasma viral load. This correlation between viral load and disease progression also holds for perinatally infected infants [98]. If this viral load can be brought down to below the detection threshold, the risk for the development of AIDS should be minimal [99]. We could thus envision that treatment with three, four (or more) different drugs in combination and at sufficiently high doses, started as early as possible during the course of the HIV infection, may completely prevent progression to the disease.

\section{ACKNOWLEDGMENTS}

The original investigations of the author are supported in part by the Biomedical Research Programme of the European Commission, the Belgian Nationaal Fonds voor Wetenschappelijk Onderzoek, the Belgian Geconcerteerde Onderzoeksacties and the Janssen, Research Foundation. I thank Christiane Callebaut for her dedicated editorial assistance. 


\section{REFERENCES}

1. De Clercq, E. J. Med. Chem. 38: 2491-2517, 1995

2. De Clercq, E. Clin. Microbiol. Rev. 8: 200-239, 1995.

3. De Clercq, E. Rev. Med. Virol. 6: 97-117, 1996.

4. De Clercq, E. In: "Insight in HIV Disease Management", Issue 6:1, Crumpacker, C.S. (ed.). Meniscus Helath Care Communications, Bala Cynwyd, Pennsylvania, USA, in press, 1997.

5. De Clercq, E. Int. J. Antimicrob. Agents, in press, 1997.

6. Kinchington, D., Minshull, C. and Drummond, C. Int. Antiviral News 4: 132-144, 1996.

7. Mitsuya, H., Popovic, M., Yarchoan, R., Matsushita, S., Gallo, R.C. and Broder, S. Science 226: 172-174, 1984

8. Schols, D., Baba, M., Pauwels, R. and De Clercq, E. J. Acquir. Immune Defic. Syndr. 2: 10-15, 1989

9. Broder, S., Yarchoan, R., Collins, J.M., Lane, H.C., Markham, P.D., Klecker, R.W., Redfield, R.R., Mitsuya, H., Hoth, D.F., Gelmann, E., Groopman, J.E., Resnick, L., Gallo, R.C., Myers, C.E. and Fauci, A.S. Lancet $i$ i: 627-630, 1985.

10. Rusconi, S., Moonis, M., Merrill, D.P., Pallai, P.V., Neidhardt, E.A., Singh, S.K., Willis, K.J., Osburne, M.S., Profy, A.T. Jenson, J.C. and Hirsch, M.S. Antimicrob. Agents Chernother. 40: 234-236, 1996.

11. Ussery, M.A., Wood, O.L., Kunder, S.C., Bacho, M.A., Broud, D.D., Papermaster, S.F., Hall, B.E., Goldberg, G.P., Hollingshead, M.G., Bader, J.P. and Black, P.L. International Workshop on HIV Drug Resistance, Treatment Strategies and Eradication, St. Petersburg, Florida, USA, 25-28 June 1997. Antiviral Therapy, p. 5, Abstract 9, 1997.

12. Lorenz, B., Leuck, J., Köhl, D., Müller, W.E.G. and Schröder, H.C. J. Acquir. Immun. Defic. Syndr. Hum. Retrovir. 14: $110-118,1997$.

13. Ojwang, J.O., Buckheit, R.W., Pommier, Y., Mazumder, A., De Vreese, K., Esté, J.A., Reymen, D., Pallansch, L.A., Lackman-Smith, C., Wallace, T.L., De Clercq, E., McGrath, M.S. and Rando, R.R. Antimicrob. Agents Chemother. 39: 2426-2435, 1995 .

14. Esté, J.A., Schols, D., De Vreese, K., Cherepanov, P., Witvrouw, M., Pannecouque, C., Debyser, Z., Rando, R.F., Desmyter, J. and De Clercq, E. Mol. Pharmacol., submitted for publication, 1997.

15. Neyts, J. and De Clercq, E. J. Acquir, Immune Defic. Syndr. Hum. Retrovir. 10: 8-12, 1995

16. Pauwels, R. and De Clercq, E. J. Acquir. Immune Defic. Syndr. Hum. Retrovir. 11:211-221, 1996.

17. Stafford, M.K., Cain, D., Rosenstein, I., Fontaine, E.A., McClure, M., Flanagan, A.M., Smith, J.R., Taylor-Robinson, D., Weber, J. and Kitchen, V.S. J. Aquir. Immun. Defic. Syndr. Hum. Retrovir. 14: 213-218, 1997

18. Simmons, G., Clapham, P.R., Picard, L., Offord, R.E., Rosenkilde, M.M., Schwartz, T.W., Buser, R., Wells, T.N.C. and Proudfoot, A.E.I. Science 276: 276-279, 1997.

19. Jansen, R.W., Molema, G., Pauwels, R., Schols, D., De Clercq, E. and Meijer, D.K.F. Mol. Pharmacol. 39: 818-823, 1991.

20. Jansen, R.W., Schols, D., Pauwels, R., De Clercq, E. and Meijer, D.K.F. Mol. Pharmacol. 44: 1003-1007, 1993.

21. Kuipers, M.E., Huisman, J.G., Swart, P.J., de Béthune, M.-P., Pauwels, R., Schuitemaker, H., De Clercq, E. and Meijer, D.K.F. J. Acquir. Immune Defic. Syndr. Hum. Retrovir, 11:419-429, 1996.

22. Swart, P.J., Kuipers, M.E., Smit, C., Pauwels, R., de Béthune, M.P., De Clercq, E., Meijer, D.K.F. and Huisman, J.G. AIDS Res. Hum. Retrovir. 12: 769-775, 1996

23. Mayaux, J.-F., Bousseau, A., Pauwels, R., Huet, T., Hénin, Y., Dereu, N., Evers, M., Soler, F., Poujade, C., De Clercq, E. and Le Pecq, J.-B. Proc. Nat. Acad. Sci. USA 91: 3564-3568, 1994.

24. Chokekijchai, S., Kojima, E., Anderson, S., Nomizu, M., Tanaka, M., Machida, M., Date, T., Toyota, K., Ishida, S., Watanabe, K., Yoshioka, H., Roller, P.P., Murakami, K. and Mitsuya, H. Antimicrob. Agents Chemother. 39: 2345-2347, 1995.

25. Lin, P.-F., Samanta, H., Bechtold, C.M., Deminie, C.A., Patick, A.K., Alam, M., Riccardi, K., Rose, R.E., White, R.J. and Colonno, R.J. Antimicrob. Agents Chemother. 40: 133-138, 1996

26. Chen, C.-H., Matthews, T.J., McDanal, C.B., Bolognesi, D.P. and Greenberg, M.L. J. Virol. 69: $3771-3777,1995$

27. Labrosse, B., Pleskoff, O., Sol, N., Jones, C., Henin, Y, and Alizon, M. International Workshop on HIV Drug Resistance, Treatment Strategies and Eradication, St. Petersburg, Florida, USA, 25-28 June 1997. Antiviral Therapy, p. 21, Abstract $33,1997$.

28. De Clercq, E., Yamamoto, N., Pauwels, R., Baba, M., Schols, D., Nakashima, H., Balzarini, J., Debyser, Z., Murrer, B.A., Schwartz, D., Thornton, D., Bridger, G., Fricker, S., Henson, G., Abrams, M. and Picker, D. Proc. Natl. Acad. Sci. USA 89: 5286-5290, 1992.

29. De Clercq, E., Yamamoto, N., Pauwels, R., Balzarini, J., Witvrouw, M., De Vreese, K., Debyser, Z., Rosenwirth, B., Peichl, P., Datema, R., Thornton, D., Skerlj, R., Gaul, F., Padmanabhan, S., Bridger, S., Henson, G. and Abrams, M. Antimicrob. Agents Chemother. 38: 668-674, 1994

30. Datema, R., Rabin, L., Hincenbergs, M., Moreno, M.B., Warren, S., Linquist, V., Rosenwirth, B., Seifert, J. and McCune, J.M. Antimicrob. Agents Chemother. 40:750-754, 1996.

31. Esté, J.A., De Vreese, K., Witvrouw, M., Schmit, J.-C., Vandamme, A.-M., Anné, J., Desmyter, J., Henson, G.W., Bridger, G. and De Clercq, E. Antiviral Res. 29: 297-307, 1996.

32. De Vreese, K., Kofler-Mongold, V., Leutgeb, C., Weber, V., Vermeire, K., Schacht, S., Anné, J., De Clercq, E., Datema, R. and Werner, G. J. Virol. 70: 689-696, 1996

33. Schols, D., Esté, J.A., Henson, G. and De Clercq, E. Antiviral Kes., in press, 1997.

34. Schols, D., Esté, J.A., Henson, G. and De Clercq, E. International Workshop on HIV Drug Resistance, Treatment Strategies and Eradication, St. Petersburg, Florida, USA, 25-28 June 1997. Antiviral Therapy, p. 2, Abstract 3, 1997.

35. Rice, W.G., Supko, J.G., Malspeis, L., Buckheit Jr., R.W., Clanton, D., Bu, M., Graham, L., Schaeffer, C.A., Turpin, J.A Domagala, J., Gogliotti, R., Bader, J.P., Halliday, S.M., Coren, L., Sowder, II, R.C., Arthur, L.O. and Henderson, L.E. Science 270: 1194-1197, 1995.

36. Rice, W.G., Baker, D.C., Schaeffer, C.A., Graham, L., Bu, M., Terpening, S., Clanton, D., Schultz, R., Bader, J.P., Buckheit Jr., R.W., Field, L., Singh, P.K. and Turpin, J.A. Antimicrob. Agents Chemother. 41: 419-426, 1997. 
37. Tummino, P.J., Scholten, J.D., Harvey, P.J., Holler, T.P., Maloney, L., Gogliotti, R., Domagala, J. and Hupe, D. Proc. Natl. Acad. Sci. USA 93: 969-973, 1996.

38. Tummino, P.J., Harvey, P.J., McQuade, T., Domagala, J., Gogliotti, R., Sanchez, J., Song, Y. and Hupe, D. Antimicrob. Agents Chemother. 4l:394-400, 1997.

39. Turpin, J.A., Terpening, S.J., Schaeffer, C.A., Yu, G., Glover, C.J., Felsted, R.L., Sausville, E.A. and Rice, W.G. J. Virol. 70:6180-6189, 1996.

40. Turpin, J.A., Schaeffer, C.A., Terpening, S.J., Graham, L., Bu, M. and Rice, W.G. Antiviral Chem. Chemother. 8: 60-69, 1997.

41. Witvrouw, M., Balzarini, J., Pannecouque, C., Jhaumeer-Laulloo, S., Esté, J.A., Schols, D., Cherepanov, P., Schmit, J.-C., Debyser, Z., Vandamme, A.-M., Desmyter, J., Ramadas, S.R. and De Clercq, E. Antimicrob. Agents Chemother, 41: 262$268,1997$.

42. Vandevelde, M., Witvrouw, M., Schmit, J.C., Sprecher, S., De Clercq, E. and Tassignon, J.-P. AIDS Res. Hum. Retrovir. I2: $567-568,1996$.

43. Rice, W.G., Turpin, J.A., Huang, M., Clanton, D., Buckheit Jr., R.W., Covell, D.G., Wallqvist, A., McDonnell, N.B., DeGuzman, R.N., Summers, M.F., Zalkow, L., Bader, J.P., Haugwitz, R.D. and Sausville, E.A. Nature Medicine 3: 341345,1997

44. Billich, A., Hammerschmid, F., Peichl, P., Wenger, R., Zenke, G., Quesniaux, V. and Rosenwirth, B. J. Virol. 69: 2451$2461,1995$.

45. Thali, M., Bukovsky, A., Kondo, E., Rosenwirth, B., Walsh, C.T., Sodroski, J. and Göttlinger, H.G. Nature 372: 363-365, 1994.

46. Franke, E.K. and Luban, J. Virology 222: 279-282, 1996

47. Mlynar, E., Bevec, D., Billich, A., Rosenwirth, B. and Steinkasserer, A. J. Gen. Virol. 78: 825-835, 1997.

48. Rosenwirth, B., Billich, A., Datema, R., Donatsch, P., Hammerschmid, F., Harrison, R., Hiestand, P., Jaksche, H., Mayer, P., Peichl, P., Quesniaux, V., Schatz, F., Schuurman, H.-J., Traber, R., Wenger, R., Wolff, B., Zenke, G. and Zurini, M. Antimicrob. Agents Chemother. 38: 1763-1772, 1994.

49. Steinkasserer, A., Harrison, R., Billich, A., Hammershmid, F., Werner, G., Wolff, B., Peichl, P., Palfi, G., Schnitzel, W., Mlynar, E. and Rosenwirth, B. J. Virol. 69: 814-824, 1995.

50. Bartz, S.R., Hohenwalter, E., Hu, M.-K., Rich, D.H. and Malkovsky, M. Proc. Natl; Acad. Sci. USA 92: 5381-5385 (1995)

51. Tantillo, C., Ding, J., Jacobo-Molina, A., Nanni, R.G., Boyer, P.L., Hughes, S.H., Pauwels, R., Andries, K., Janssen, P.A.J. and Arnold, E. J. Mol. Biol. 243: 369-387, 1994.

52. Daluge, S.M., Good, S.S., Faletto, M.B., Miller, W.H., St. Clair, M.H., Boone, L.R., Tisdale, M., Parry, N.R., Reardon, J.E., Dornsife, R.E., Averett, D.R. and Krenitsky, T.A. Antimicrob. Agents Chemother. 41: 1082-1093, 1997.

53. Tisdale, M., Alnadaf, T. and Cousens, D. Antimicrob. Agents Chemother, 41: 1094-1098, 1997.

54. Faletto, M.B., Miller, W.H., Garvey, E.P., St. Clair, M.H., Daluge, S.M. and Good, S.S. Antimicrob. Agents Chemother. 41: 1099-1107, 1997.

55. De Clercq, E. Biochem. Pharmacol. 42: 963-972, 1991

56. Naesens, L., Snoeck, R., Andrei, G., Balzarini, J., Neyts, J. and De Clercq, E. Antiviral Chem. Chemother. 8: 1-23, 1997.

57. Tsai, C.-C., Follis, K.E., Sabo, A., Beck, T.W., Grant, R.F., Bischofberger, N., Benveniste, R.E. and Black, R. Science 270: 1197-1199, 1995.

58. Buckheit Jr., R.W., Snow, M.J., Fliakas-Boitz, V., Kinjerski, T.L., Russell, J.D., Pallansch, L.A., Brouwer, W.G. and Yang, S.S. Antimicrob. Agents Chemother. 41: 831-837, 1997

59. Esnouf, R., Ren, J., Hopkins, A.L., Ross, C.K., Jones, E.Y., Stammers, D.K. and Stuart, D.I. Proc. Natl. Acad. Sci. USA 94: 3984-3989, 1997.

60. Kleim, J.-P., Winkler, 1., Rösner, M., Kirsch, R., Rübsamen-Waigmann, H., Paessens, A. and Riess, G. Virology 231: 112$118,1997$.

61. Cherepanov, P., Esté, J.A., Rando, R.F., Ojwang, J.O., Reekmans, G., Steinfeld, R., David, G., De Clercq, E. and Debyser, Z. Mol. Pharmacol., in press, 1997.

62. Esté, J.A., Schols, D., De Vreese, K., Van Laethen, K., Vandamme, A.-M., Desmyter, J. and De Clercq, E. Mol. Pharmacol., in press, 1997.

63. Robinson, W.E. Jr., Reinecke, M.G., Abdel-Malek, S., Jia, Q. and Chow, S.A. Proc. Natl. Acad. Sci. USA 93: 6326-6331, 1996.

64. Robinson, W.E. Jr., Cordeiro, M., Abdel-Malek, S., Jia, Q., Chow, S.A., Reinecke, M.G. and Mitchell, W.M. Mol. Pharmacol. 50: 846-855, 1996.

65. Neamati, N., Hong, H., Mazumder, A., Wang, S., Sunder, S., Nicklaus, M.C., Milne, G.W.A., Proksa, B. and Pommier, Y. J. Med. Chem. 40: 942-951, 1997.

66. Zhao, H., Neamati, N., Sunder, S., Hong, H., Wang, S., Milne, G.W.A.. Pommier, Y. and Burke Jr., T.R. J. Med. Chem. 40: $937-941,1997$

67. Sourgen, F., Maroun, R.G., Frère, V., Bouziane, M., Auclair, C., Troalen, F. and Fermandjian, S. Eur. J. Biochem. 240: 765-773, 1996.

68. Neamati, N., Mazumder, A., Zhao, H., Sunder, S., Burke Jr., T.R., Schultz, R.J. and Pommier, Y. Antimicrob. Agents Chemother. 41: 385-393, 1997.

69. Mazumder, A., Wang, S., Neamati, N., Nicklaus, M., Sunder, S., Chen, J., Milne, G.W.A., Rice, W.G., Burke Jr., T.R. and Pommier, Y. J. Med. Chem. 39: 2472-2481, 1996.

70. Hsu, M.-C., Schutt, A.D., Holly, M., Slice, L.W., Sherman, M.I., Richman, D.D., Potash, M.J. and Volsky, D.J. Science 254: 1799-1802, 1991

71. Kira, T., Hashimoto, K.-I., Baba, M., Okamoto, T. and Shigeta, S. Antiviral Res. 32: 55-62, 1996.

72. Witvrouw, M., Pauwels, R., Vandamme, A.-M., Schols, D., Reymen, D., Yamamoto, N., Desmyter, J. and De Clercq, E. Antimicrob. Agents Chemother. 36: 2628-2633, 1992.

73. Kashanchi, F., Sadaie, M.R. and Brady, J.N. Virology 227: 431-438, 1997. 
74. Hamy, F., Felder, E.R., Heizmann, G., Lazdins, J., Aboul-Ela, F., Varani, G., Karn, J. and Klimkait, T. Proc. Natl. Acad. Sci. USA 94: 3548-3553, 1997.

75. De Clercq, E. Biochem. Pharmacol. 36: 2567-2575, 1987.

76. Daelemans, D., Esté, J.A., Witvrouw, M., Pannecouque, C., Jonckheere, H., Perno, C.-F., De Clercq, E. and Vandamme, A.-M. Mol. Pharmacol., submitted for publication, 1997.

77. Bordier, B., Perala-Heape, M., Degols, G., Lebleu, B., Litvak, S., Sarih-Cottin, L. and Hélène, C. Proc. Natl. Acad. Sci. USA 92: 9383-9387, 1995.

78. Temsamani, J. and Agrawal, S. In: Advances in Antiviral Drug Design, vol. 2, De Clercq, E. (ed.), JAJ Press Inc., Greenwich, Connecticut, USA, p. 1-39, 1996.

79. Lisziewicz, J., Sun, D., Weichold, F.F., Thierry, A.R., Lusso, P., Tang, J., Gallo, R.C. and Agrawal, S. Proc. Natl. Acad. Sci. USA 91: 7942-7946, 1994

80. Zhang, R., Diasio, R.B., Lu, Z., Liu, T., Jiang, Z., Galbraith, W.M. and Agrawal, S. Biochem. Pharmacol. 49: 929-939, 1995.

81. Agrawal, S., Jiang, Z., Zhao, Q., Shaw, D., Cai, Q., Roskey, A., Channavajjala, L., Saxinger, C. and Zhang, R. Proc. Natl. Acad. Sci. USA 94: 2620-2625, 1997.

82. Fischer, P.B., Karlsson, G.B., Dwek, R.A. and Platt, F.M. J. Virol. 70: 7153-7160, 1996.

83. Kim, C.U., McGee, L.R., Krawczyk, S.H., Harwood, E., Harada, Y., Swaminathan, S., Bischofberger, N., Chen, M.S., Cherrington, J.M., Xiong, S.F., Griffin, L., Cundy, K.C., Lee, A., Yu, B., Gulnik, S. and Erickson, J.W. J. Med. Chem. 39: $3431-3434,1996$.

84. Hultén, J., Bonham, N.M., Nillroth, U., Hansson, T., Zuccarello, G., Bouzide, A., Åqvist, J., Classon, B., Danielson, U.H., Karlén, A., Kvarnström, I., Samuelsson, B. and Hallberg, A. J. Med. Chem. 40: 885-897, 1997.

85. Bäckbro, K., Löwgren, S., Österlund, K., Atepo, J., Unge, T., Hultén, J., Bonham, N.M., Schaal, W., Karlén, A. and Hallberg, A. J. Med. Chem. 40: 898-902, 1997.

86. De Lucca, G.V., Liang, J., Aldrich, P.E., Calabrese, J., Cordova, B., Klabe, R.M., Rayner, M.M. and Chang, C.-H. J. Med. Chem. 40: 1707-1719, 1997.

87. Poppe, S.M., Slade, D.E., Chong, K.-T., Hinshaw, R.R., Pagano, P.J., Markowitz, M., Ho, D.D., Mo, H., Gorman III, R.R., Dueweke, T.J., Thaisrivongs, S. and Tarpley, W.G. Antimicrob. Agents Chemother. 41: 1058-1063, 1997.

88. Saag, M.S., Holodniy, M., Kuritzkës, D.R., O'Brien, W.A., Coombs, R., Poscher, M.E., Jacobsen, D.M., Shaw, G.M., Richman, D.D. and Volberding, P.A. Nature Medicine 2: 625-629, 1996.

89. Kempf, D.J., Marsh, K.C., Kumar, G., Rodrigues, A.D., Denissen, J.F., McDonald, E., Kukulka, M.J., Hsu, A., Granneman, G.R., Baroldi, P.A., Sun, E., Pizzuti, D., Plattner, J.J., Norbeck, D.W. and Leonard, J.M. Antimicrob. Agents Chemother. 4J:654-660, 1997.

90. Balzarini, J., Karlsson, A., Pérez-Pérez, M.-J., Camarasa, M.-J, and De Clercq, E. Virology 196: 576-585, 1993.

91. Balzarini, J., Karlsson, A., Meichsner, C., Paessens, A., Riess, G., De Clercq, E. and Kleim, J.-P. J. Virol. 68: 7986-7992, 1994.

92. Balzarini, J., Pelemans, H., Aquaro, S., Perno, C.-F., Witvrouw, M., Schols, D., De Clercq, E. and Karlsson, A. Mol. Pharmacol. 50: 394-401, 1996.

93. Balzarini, J., Pelemans, H., Pérez-Pérez, M.J., San-Félix, A., Camarasa, M.-J., De Çlercq, E. and Karlsson, A. Mol. Pharmacol. 49: 882-890, 1996.

94. Lange, J.M.A. Science 276: 548-550, 1997.

95. van Leeuwen, R., Bonsel, G.J., Reiss, P., Danner, S.A. and Lange, J.M.A. J. Infect. Dis. 175: 1344-1351, 1997.

96. Luzuriaga, K., Bryson, Y., Krogstad, P., Robinson, J., Stechenberg, B., Lamson, M., Cort, S. and Sullivan, J.L. N. Engl. J. Med. 336: 1343-1349, 1997.

97. Mellors, J.W., Rinaldo, C.R. Jr., Gupta, P., White, R.M., Todd, J.A. and Kingsley, L.A.. Science 272: 1167-1170, 1996.

98. Shearer, W.T., Quinn, T.C., LaRussa, P., Lew, J.F., Mofenson, L., Almy, S., Rich, K., Handelsman, E., Diaz, C., Pagano, M., Smeriglio, V. and Kalish, L.A. N. Engl. J. Med. 336: 1337-1342, 1997.

99. Ho, D.D. Science 272: 1124-1125, 1996. 